\title{
A Fluorometric Method for the Determination of Iron(II) with Fluorescein Isothiocyanate and Iodine
}

\author{
Guohui ZHU, Zhancai ZHU, and Lanfang QIU \\ Department of Chemical Engineering, Zhangzhou Vocational University, \\ Zhangzhou, Fujian 363000, P. R. China
}

(Received November 26, 2001; Accepted April 17, 2002)

Iron(II) has wide physiological functions. It is an essential trace element in the human body. It is also a main cure for several diseases, such as anemia. Thus, the determination of iron(II) is very important. Several methods have been reported, except spectrophotometry, such as anodic stripping voltammetry, volumetric analysis, ${ }^{2}$ fluorometric analysis, ${ }^{3,4}$ and atomic spectroscopy. ${ }^{5}$ However, to our knowledge, report concerning a fluorescence method for iron(II) by using fluorescein isothiocyanate as a fluorescence reagent has not yet appeared. In the present work, a fluorescence enhancing method for iron(II) was developed based on fluorescein isothiocyanate (FITC) with iodine to produce a non-fluorescence species result in fluorescence quenching. Iron(II) could compete with fluorescein isothiocyanate to react with iodine, resulting in a fluorescence enhancement of the system. This method is simple and sensitive compared with dynamic fluorometry, ${ }^{3}$ and has been applied to the determination of iron(II) in samples with satisfactory results.

\section{Experimenal}

\section{Apparatus}

An LS-30 spectrofluorometer (Perkin Elmer) was used for recording the spectra and making fluorescence measurements. All of the $\mathrm{pH}$ measurements were made with a Model PHS-3B pH meter (Shanghai, China).

\section{Reagents}

All chemicals were of analytical reagent grade or of the highest purity available. All aqueous solutions were made up in distilled, deionized water. A ferrous stock solution $(0.2 \mathrm{mg} / \mathrm{ml})$ was prepared by dissolving $24.9 \mathrm{mg}$ of $\mathrm{FeSO}_{4} \cdot 7 \mathrm{H}_{2} \mathrm{O}$ in $25 \mathrm{ml}$ of water. Solutions $(2.0 \mu \mathrm{g} / \mathrm{ml})$ were prepared daily from the stock solution by appropriate dilution with water. A fluorescein isothiocyanate solution $\left(1.0 \times 10^{-4} \mathrm{~mol} / \mathrm{l}\right)$ was prepared by dissolving an appropriate weight of fluorescein isothiocyanate in ethanol and diluting to the required volume. This solution was diluted to $1.0 \times 10^{-6} \mathrm{~mol} / \mathrm{l}$ as a working solution. An iodine stock solution $(1.0 \mathrm{mg} / \mathrm{ml})$ was prepared by dissolving $0.100 \mathrm{~g}$ of iodine in ethanol and diluting to volume in a $100 \mathrm{ml}$ standard flask. The solution was diluted to $40 \mu \mathrm{g} / \mathrm{ml}$ with ethanol as the working solution (prepared daily). Citric acid-sodium hydrogenphosphate buffer solutions $(0.01 \mathrm{~mol} / \mathrm{l}, \mathrm{pH} 5.40$ - 7.60) were used.

\section{Procedure}

To a $10 \mathrm{ml}$ standard flask transferred $0.10 \mathrm{ml}$ of a $1.0 \times 10^{-6}$ $\mathrm{mol} / \mathrm{l}$ fluorescein isothiocyanate solution, $0.60 \mathrm{ml}$ of a buffer solution ( $\mathrm{pH}$ 6.40), and a known volume of a iron(II) standard solution. Then $0.09 \mathrm{ml}$ of an iodine solution $(40 \mu \mathrm{g} / \mathrm{ml})$ was added and diluted to the mark with water, and mixed. The fluorescence intensity was then measured against a reagent blank at $515 \mathrm{~nm}$ with excitation at $485 \mathrm{~nm}$.

\section{Results and Discussion}

\section{Spectral characteristics}

The excitation and emission spectra of fluorescein isothiocyanate, fluorescein isothiocyanate- $\mathrm{I}_{2}$ and fluorescein isothiocyanate- $\mathrm{I}_{2}-\mathrm{Fe}^{2+}$ systems are shown in Fig. 1. It can be seen that the fluorescence spectra of the three systems are similar. The maximal excitation and emission wavelengths were at 485 $\mathrm{nm}$ and at $515 \mathrm{~nm}$, respectively. However, the fluorescence intensity $(F)$ of the fluorescein isothiocyanate- $\mathrm{I}_{2}$ system was greatly enhanced when $\mathrm{Fe}^{2+}$ was added.
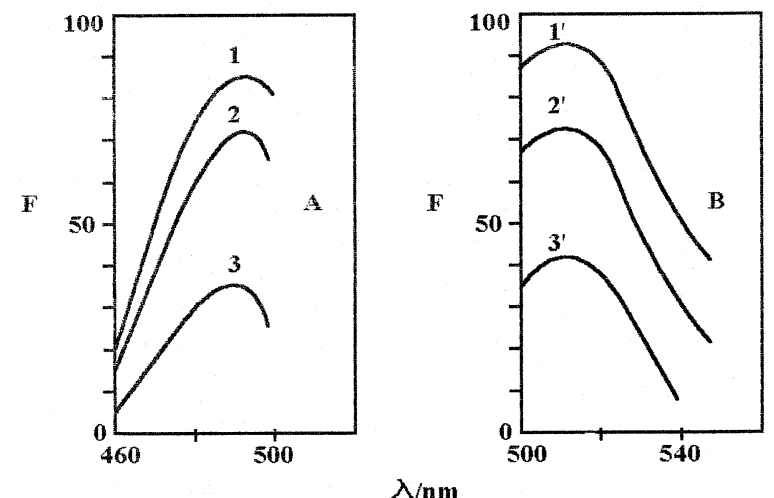

Fig. 1 Excitation (A) and emission (B) of fluorescein isothiocyanate $\left(1,1^{\prime}\right)$, fluorescein isothiocyanate- $\mathrm{I}_{2}-\mathrm{Fe}^{2+}\left(2,2^{\prime}\right)$ and fluorescein isothiocyanate- $I_{2}$ system $\left(3,3^{\prime}\right)$. Fluorescein isothiocyanate solution: $1.0 \times 10^{-8} \mathrm{~mol} / \mathrm{l}$; iodine solution: $0.36 \mu \mathrm{g} / \mathrm{ml}$; Fe(II) solution: $100 \mathrm{ng} / \mathrm{ml}$ citric acid-sodium hydrogenphosphate buffer solution: $\mathrm{pH} 6.44$. 


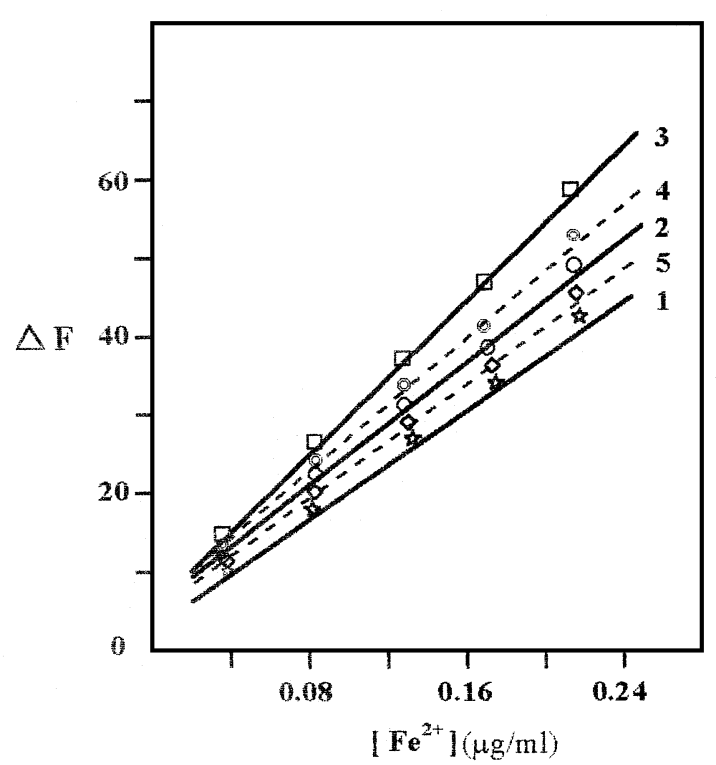

Fig. 2 The effect of concentration of iodine on fluorescence enhancement. Iodine concentration $(\mu \mathrm{g} / \mathrm{ml})$ : (1) 0.28 , (2) 0.32 , (3) 0.36 , (4) 0.40 (5) 0.44 . Fluorescein isothiocyanate solution: $1.0 \times$ $10^{-8} \mathrm{~mol} / \mathrm{l}$.

\section{Optimum conditions for the fluorescence determination}

The effect of the concentration of iodine on the fluorescence enhancement was studied (Fig. 2). It can be seen that the highest sensitivity of the proposed method was achieved when the concentration of iodine was $0.36 \mu \mathrm{g} / \mathrm{ml}$. The sensitivity decreased when the iodine concentration was lower or higher than this value. When the concentration of a fluorescein isothiocyanate solution was in the range of $0.8 \times 10^{-8}-1.2 \times 10^{-8}$ $\mathrm{mol} / \mathrm{l}$, the fluorescein enhancement was maximal and constant. In this work, concentrations of $0.36 \mu \mathrm{g} / \mathrm{ml} \mathrm{I}_{2}$ solution and $1.0 \times$ $10^{-8} \mathrm{~mol} / \mathrm{l}$ fluorescein isothiocyanate solution were employed.

The effect of the $\mathrm{pH}$ on the fluorescence enhancement was also examined. The results showed that the maximum fluorescence enhancement occurred at a $\mathrm{pH}$ of 6.40. Therefore, a $\mathrm{pH}$ of 6.40 is recommended for use, achieved via the addition of $0.60 \mathrm{ml}$ of a buffer solution per $10 \mathrm{ml}$ of the final solution. The concentration of the final buffer solution was $6.0 \times 10^{-4}$ $\mathrm{mol} / \mathrm{l}$.

The influence of the setting time was investigated. The results indicated that the reaction was finished immediately, and that the difference in the fluorescence intensity between the FITC- $\mathrm{I}_{2}$ $\mathrm{Fe}^{2+}$ and the FITC-I $\mathrm{I}_{2}$ blank remained constant for $120 \mathrm{~min}(18-$ $\left.24^{\circ} \mathrm{C}\right)$.

\section{Interferences}

The tolerance limits of 46 types of foreign substances for the determination of $0.1 \mu \mathrm{g} / \mathrm{ml} \mathrm{Fe} \mathrm{Fe}^{2+}$ by the described procedure were studied. The results are listed in Table 1 . When the relative error was less than $\pm 5 \%$, these substances did not interfere with the determination of $\mathrm{Fe}^{2+}$.

\section{Calibration graph}

A calibration graph for the determination of iron(II) was constructed under the optimum conditions. A linear relationship between the iron(II) concentration and the fluorescence enhancement was obtained over the range of 40 $200 \mathrm{ng} / \mathrm{ml}$. The regression for the line and correlation coefficient fit by the least square method are $\Delta F=0.297 C-$ $0.076, r=0.9999$ (the unit of $C$ is $\mathrm{ng} / \mathrm{ml}$ ). The detection limit
Table 1 Tolerance limit for different species in the determination of $0.1 \mu \mathrm{g} / \mathrm{ml} \mathrm{Fe}^{2+}$

\begin{tabular}{|c|c|}
\hline Species & $\begin{array}{l}\text { Tolerance limit } \\
\text { (molar ratio) }\end{array}$ \\
\hline $\mathrm{Na}^{+}$ & 1000 \\
\hline $\mathrm{NH}_{4}^{+}$ & 310 \\
\hline $\mathrm{F}^{-}$, citrate & 294 \\
\hline $\mathrm{SiO}_{3}{ }^{2-}, \mathrm{Ca}^{2+}$ & 251 \\
\hline $\mathrm{Mg}^{2+}, \mathrm{Mn}^{2+}$ & 230 \\
\hline $\mathrm{PO}_{4}^{3-}$ & 180 \\
\hline $\mathrm{Cl}^{-}, \mathrm{K}^{+}$ & 145 \\
\hline $\mathrm{NO}_{3}^{-}$ & 121 \\
\hline $\mathrm{SO}_{4}{ }^{2-}$ & 105 \\
\hline $\mathrm{Cu}^{2+}$ & 88 \\
\hline Sugar, L-Ala, Gly, L-Glu & 65 \\
\hline $\begin{array}{l}\mathrm{Cr}^{3+}, \mathrm{Ba}^{2+}, \mathrm{Co}^{2+}, \mathrm{Ni}^{2+}, \mathrm{SO}_{3}{ }^{2-}, \\
\mathrm{AsO}_{4}^{3-}, \mathrm{SbO}_{4}^{3-}\end{array}$ & 40 \\
\hline $\begin{array}{l}\mathrm{Ag}^{+}, \mathrm{Zn}^{2+}, \mathrm{Pb}^{2+}, \mathrm{CrO}_{4}{ }^{2-}, \mathrm{AsO}_{3}{ }^{3-}, \\
\mathrm{SbO}_{3}{ }^{3-},\end{array}$ & 30 \\
\hline $\begin{array}{l}\text { L-Tyr, ascorbic acid, vitamin } B_{1} \text {, } \\
\text { vitamin } B_{6}\end{array}$ & 23 \\
\hline $\begin{array}{l}\mathrm{CO}_{3}^{2-}, \mathrm{VO}_{3}^{-}, \mathrm{NO}_{2}^{-}, \mathrm{Sr}^{2+} \text {, ascorbic } \\
\text { acid }\end{array}$ & 13 \\
\hline $\mathrm{S}^{2-}, \mathrm{VO}_{4}^{3-}, \mathrm{Fe}^{3+}, \mathrm{Al}^{3+}$ & 7 \\
\hline $\mathrm{Br}^{-}$ & 5 \\
\hline
\end{tabular}

$(3 \sigma)$ for $\mathrm{Fe}^{2+}$ was calculated from the standard deviation $(n=$ 10) of the blank as $15 \mathrm{ng} / \mathrm{ml}$. The precision of the method was established by a replicate determination $(n=10)$. Using 100 $\mathrm{ng} / \mathrm{ml}$ of $\mathrm{Fe}^{2+}$ gave a relative standard deviation of $1.9 \%$.

\section{Sample determination}

The pretreatment and procedures of the sample analysis are expressed as follows. The samples of water were filtrated on a filter tunnel with a fine-mesh velamen membrane $(\phi 0.45 \mu \mathrm{m})$. Samples of $500 \mathrm{~g}$ of soil were mixed and impregnated for $24 \mathrm{~h}$ with $500 \mathrm{ml}$ of water. Each sample was then filtrated on a filter tunnel with fibrous glass into filtrate receiver, then filtration was filtrated on the filter tunnel with a fine-mesh velamen membrane. The samples of water, and to make use of water of impregnating soil, were preserved with $100 \mu \mathrm{H}_{2} \mathrm{SO}_{4}$ per 100 ml. A ferrous gluconate syrup with $3.5 \mathrm{mg} \mathrm{Fe} \mathrm{Fe}^{2+} / \mathrm{ml}$ was diluted to $3.5 \mu \mathrm{g} \mathrm{Fe}{ }^{2+} / \mathrm{ml}$ as an analytical solution with water. A pharmaceuticals solution of $2.0 \mu \mathrm{g} \mathrm{Fe} \mathrm{Fe}^{2+} / \mathrm{ml}$ was prepared by dissolving $14.2 \mathrm{mg}$ of ammonium iron(II) sulfate with a labeled value of $142 \mathrm{mg} / \mathrm{g} \mathrm{Fe}^{2+}$ in $1000 \mathrm{ml}$ of water. The proposed method was then applied to determine iron(II) in an analytic solution of water, soils, iron(II) gluconate syrups and pharmaceuticals. The results are summarized in Tables 2 and 3. The possibility of using this method for the analysis of real samples was tested by determining the recovery. In recovery experiments, known amounts of the iron(II) standard solution were added to samples of the water or soil, which were then pretreated as stated above. The results are summarized in Tables 2 and 3. The results show that the recoveries were satisfactory.

\section{Conclusions}

The proposed fluorometric method for the determination of iron(II) is highly sensitive and selective. The procedure is rapid and simple, and the results are reproducible. 
Table 2 Determination of iron(II) in water and syrup

\begin{tabular}{|c|c|c|c|c|c|c|}
\hline \multirow[b]{2}{*}{ Sample } & \multicolumn{2}{|c|}{ Found value $/ \mu \mathrm{g} \mathrm{ml}^{-1}$} & \multirow[b]{2}{*}{ RE, \% } & \multirow[b]{2}{*}{ Added/ $\mu \mathrm{g}$} & \multirow[b]{2}{*}{ Found total value ${ }^{\mathrm{b}} / \mu \mathrm{g}$} & \multirow[b]{2}{*}{ Recovery $^{\mathrm{c}}, \%$} \\
\hline & This method & $\begin{array}{l}\text { 1,10-Phenanthroline } \\
\text { spectrophotometry }\end{array}$ & & & & \\
\hline Natural mineral water & 0.062 & 0.064 & -3.1 & 1.00 & 1.42 & 92 \\
\hline Under ground water & 0.091 & 0.094 & -3.2 & 1.00 & 1.69 & 96 \\
\hline Hot spring water & 0.123 & 0.115 & +7.0 & 1.00 & 1.88 & 90 \\
\hline Iron(II) gluconate syrup & $3.68 \times 10^{3}$ & $3.50^{\mathrm{d}} \times 10^{3}$ & +5.1 & - & - & - \\
\hline
\end{tabular}

a. Mean of six determinations. b. $8 \mathrm{ml}$ samples of water $+1.00 \mu \mathrm{g} \mathrm{Fe}{ }^{2+}$. c. Recovery $(\%)=($ found total value - found value of $8.0 \mathrm{ml}$ of water samples)/added $\times 100$. d. Labeled value: $3.5 \mathrm{mg} / \mathrm{ml}$ of $\mathrm{Fe}^{2+}$.

Table 3 Determination of iron(II) in soil and pharmaceuticals

\begin{tabular}{|c|c|c|c|c|c|c|}
\hline \multirow[b]{2}{*}{ Sample } & \multicolumn{2}{|c|}{ Found value $/ \mu \mathrm{g} \mathrm{g}^{-1}$} & \multirow[b]{2}{*}{ RE, \% } & \multirow[b]{2}{*}{ Added/ $/ \mu \mathrm{g}$} & \multirow[b]{2}{*}{ Found total value/ $\mu \mathrm{g}$} & \multirow[b]{2}{*}{ Recovery $^{\mathrm{b}}, \%$} \\
\hline & This method & $\begin{array}{l}\text { 1,10-Phenanthroline } \\
\text { spectrophotometry }\end{array}$ & & & & \\
\hline Red soil & 0.075 & 0.077 & -2.6 & 0.50 & 1.07 & 94 \\
\hline$(8 \mathrm{~g})$ & & & & 1.00 & 1.56 & 96 \\
\hline Black soil & 0.68 & 0.67 & +1.5 & 0.50 & 1.15 & 94 \\
\hline$(1 \mathrm{~g})$ & & & & 1.00 & 1.63 & 95 \\
\hline Ammonium ferrous sulfate & $1.39 \times 10^{5}$ & $1.42 \times 10^{5}$ & -2.1 & - & - & - \\
\hline
\end{tabular}

a. Mean of six determinations. b. Recovery $(\%)=($ found total value - found value of $X \mathrm{~g}$ of soil samples $) /$ added $\times 100$.

\section{References}

1. S. Sundd, S. K. Prasad, A. Kumar, and B. B. Prasad, Talanta, 1994, 41, 1943.

2. D. Tzur, V. Dosortzev, and E. Kirowa-Eisne, Anal. Chim. Acta, 1999, 392, 307.
3. F. Garcla Sanchez, A. Navas Dlaz, and J. J. Laserna, Anal. Chem., 1983, 55, 253.

4. S. Bao, G. Wang, B. Liu, H. Sun, Y. Huang, and S. Shi, Chin. J. Spectrosc. Spectral Anal., 2001, 21, 87.

5. S. Veres and A. Csikkelszolnoki, Magyar Kemiai Folyoirat, 1992, 98, 453. 